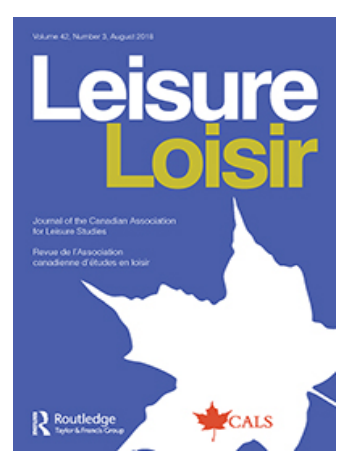

Leisure/Loisir

\title{
Scriptural illustration applied in the homo faber- religious-ludens spiritual model of leisure
}

\section{Gervais Deschênes}

To cite this article: Gervais Deschênes (2018) Scriptural illustration applied in the homo faber-religious-ludens spiritual model of leisure, Leisure/Loisir, 42:3, 259-279, DOI:

10.1080/14927713.2018.1535909

To link to this article: https://doi.org/10.1080/14927713.2018.1535909

册 Published online: 11 Dec 2018.

Submit your article to this journal $\pi$

山 Article views: 10

View Crossmark data ¿ 


\section{Scriptural illustration applied in the homo faber-religious- ludens spiritual model of leisure}

\section{Gervais Deschênes}

Département des sciences de l'éducation, Université du Québec à Chicoutimi, Chicoutimi, Québec, Canada

\section{ABSTRACT}

The intention of this article is to convey the ternary relationship of humanity models specific to leisure studies. Thus with a view to bridge the gaps between the three humanity models, namely - the homo faber - persons at work, - the homo ludens - persons at play, and - the homo religious persons primarily religious/spiritual, this article uses hermeneutics to explore these models' contributions in the current context by presenting an illustration: the scriptural narrative of Lord Jesus as homo religious within the gospel story Jesus Visits Martha and Mary in which Martha represents homo faber and Mary of Bethany homo ludens. Homo faber-religious-ludens is a spiritual model of leisure characterized by the dynamic relationships between the three humanity models that are pertinent to the social world and the communities of the post-secular era.

\section{RÉSUMÉ}

L'intention de cet article est de communiquer les relations de trois modèles d'humanité propre aux études en loisir. Ainsi, dans une vision de créer des liens entre ces trois modèles d'humanité -l'homo faber - les personnes au travail, - I'homo ludens - les personnes au jeu et - I'homo religious - les personnes principalement religieux/spirituel, cet article emploi l'herméneutiques pour explorer les contributions de ces trois modèles dans le contexte d'aujourd'hui en présentant une démonstration biblique du Seigneur Jésus comme homo religious à partir de la péricope Chez Marthe et Marie dans lequel Martha représente l'homo faber et Marie de Béthanie l'homo ludens. L'homo faber-religiousludens est un modèle spirituel du loisir caractérisé par les relations dynamiques entre les trois modèles d'humanité qui sont pertinents au monde social et des communautés. L'homo faber-religious-ludens est un modèle spirituel du loisir caractérisé par les relations dynamiques entre les trois modèles d'humanité qui sont pertinents au monde social et des communautés de l'ère post-séculière.

\section{ARTICLE HISTORY}

Received 10 February 2017

Accepted 28 November 2017

\section{KEYWORDS}

Practical theology; hermeneutics; wisdom and logos; work/play; Christian spirituality of leisure

\section{MOTS-CLÉS}

théologie pratique;

herméneutiques; sagesse et logos; travail/jeu; spiritualité chrétienne du loisir

CONTACT Gervais Deschênes gervais_deschenes@uqac.ca Université du Québec à Chicoutimi, 555, boul. de I'Université, Chicoutimi, Québec G7H 2B1, Canada

This article has been republished with minor changes. These changes do not impact the academic content of the article. 
"Eternity is a child playing draughts, the kingly power is a child's".

- Heraclitus

Fragment 52

\section{Genesis of questioning}

Most people today have to struggle to live in a society of overconsumption, high productivity and extreme perfectionism. In fact, to find work is no longer guaranteed and many people in the aging society find themselves with increased free time and thus leisure has a major place in their timetable. This fluid variable necessarily has implications in the spiritual model of leisure entitled the homo faber-religious-ludens (cf. Bellehumeur, Deschênes, \& Malette, 2012; Deschênes, 2011b, 2015, 2016). This complex view of the mind inside the Christian faith is briefly defined as an anthropological journey that allows one to be globally structured and to interact symbolically as an authentic person through the path of life. Definitely, leisure is a serious matter. It has been viewed as a creative process in which existential meaning of life are created and shared within the context of the social world and the communities where people are immersed (cf. Gallant, Arai, \& Smale, 2013; Kelly, 1987). Leisure is also ideological and is undoubtedly shaped by education which is a determinating factor in preventing alienation (Dumont, 1981). From this last viewpoint, it is suggested that the homo faber-religious-ludens spiritual model of leisure is illustrated by the gospel story Jesus Visits Martha and Mary (St. Luke, 10: 38-42) which provides a biblical picture of the relationships between three humanity models: Martha as the homo faber, Mary as the homo ludens and the Lord Jesus as the homo religious par excellence. These humanity models have determined the behaviours of people throughout history and the connections between them are enhanced by an understanding of Christian scripture which is still applicable to spiritual quests in the present context of the post-secular era characterized by detraditionalization, individualization and pluralization of religion (Braeckman, 2010; Habermas, 2008). This reconfiguration of religion should be viewed with the understanding that the secularization thesis no longer applies as Boeve (2012) attests:

[...] modernisation of society does not lead simply to the disappearance of religion, but rather to a changed way of dealing with religion, as well as to its pluralization. The zero-point theory, honoured by secularization thesis, which holds that the more modernisation there is the less religion remains (and the opposite, the more religion there is, the less modernized a society is), no longer holds. Even more: whoever claims today that the outcome of social processes necessarily leads to a situation where religion may no longer have public meaning, and at best can be but a private matter, is unmasked as being ideological. (p. 145) 
This theological perspective reaffirms that every person may have a real sense of meaning. Everyone is unique and all lives are sacred. Therefore, each person belongs to the universe of humankind (Mounier 1950/1952), which allows for meaning of life of people who are seeking eternal salvation in spite of suffering and false consciousness.

In this article, we will propose conceptual definitions of three humanity models: homo faber, homo ludens and homo religious. Subsequently, we will give a definition of the spiritual model of leisure known as homo faber-religiousludens. Next, some basic principles will be provided about philosophical hermeneutics, the method used in this study. Finally, in order to illustrate the practical application of this spiritual model of leisure, we will present the gospel story Jesus Visits Martha and Mary and explain its relevance to the social world and the communities of today's post-secular era.

\section{Conceptual definitions of the three humanity models}

To begin our discussion, we need to define briefly the three humanity models, namely the homo faber, the homo ludens and the homo religious each of which exists in the social world and the communities of today's post-secular era.

\section{The homo faber humanity model}

Throughout the past two centuries, intelligentsia in many countries have debated the struggle for life. The dogma of work - the homo faber - has determined time use and resulted to the exploitation of humans by humans. For instance, during the Industrial Revolution, people, including children, worked from 12 to 14 hours per day in coal mines and textile manufacturing. Industrialization led to urbanization and included the related changes to agricultural as people began leaving farms to move to urban areas. The problems of the homo faber within capitalism were raised by Lafargue (1883/2012), who realized the perversity of work for humans during this revolutionary period of history. For him, the absolutism of work is, to some extent, the cause of all physical deformity, intellectual degeneracy and human exhaustion.

According to Schor (1992), work itself represents in some way a time ethic because time is money: ' $[\mathrm{m}]$ oney buys time, and time buys money. Time itself had become a commodity' (p. 139). For Haworth and Lewis (2005), the homo faber is considered to be paid work and unpaid work including domestic labour, childcare and voluntary activities. Work, by providing status and self-esteem, is the spine which structures the manner in which people live, and how they relate to material and social reality. This inclusive definition of work leaves no space for free time and rest. People are situated in a world of work where other activities lose their 
sense of meaning. Kelly and Freysinger (1999) testifies that within the work environment, there is pride in doing the job well; work is then a central social identity for most people.

\section{The homo ludens humanity model}

Play has an existential ontological framework and a state-of-being described by joy of living and inner peace. In the context of overconsumption, high productivity and extreme perfectionism, play becomes a type of escape from reality wherein its healing function can be lost. Although play may bring healing, it is primarily an activity done for its own sake instead of a means to achieve a goal. Play has deep relevance for human life (Caillois, 1958/1967). This temporal activity leads to positive or negative experiences, and substantially contributes to the meaning of life because of its existential features. For Parker, Ventris, Haworth, and Smith (1978), play permits a state of social being where people freely choose activities that enhance and reflect their control over their everyday life.

Just before World War II, Huizinga (1938/1955) proposed a clear understanding of play as homo ludens which represents people as players who create culture. This concept is important because historically, play was fundamental in the creation of many elements of culture such as the law and justice, politics, wisdom, art and poetry, education, war and peace, imagination and religion. Play contains its own goals that produce the feelings of joy and pleasure, tension and real self-consciousness. Play is sometimes typified by its agonistic or competitive nature, which finds its roots in many forms of sacred manifestations.

Indeed, most people have their own particular meanings of play. Play is perceived as irrational, serious and not foolish. It provides a cosmological event and opportunity for people to discover their highest and holiest expressions (Huizinga, 1938/1955) within the form and function of play, by itself an independent entity, which is irrational and senseless. Too often, play leads to its falsification due to the personal desire to compete. This means that each person tries to be better than others and is mainly motivated by self-adulation. This competitive dimension of play carries with it negative consequences. For example, over the past 80 years, theologians and philosophers have specified the seriousness and non-seriousness of play. Fink (1966) concluded that the course of the world is without reason, meaning at the least that the social world has no aim or finality. In light of such philosophical and theological understandings, by all means, men and women are necessarily playful. They are unable to function against the Spirit of the world. Fink (1955/2012) conceptualized play as a binding power that is philosophically more nurturing and less oppressive than work in today's post-secular era: play belongs to the ontological formation of people' 
identities and the life meaning. As a result, play implies the freedom of being. For Bickley (2014), it is also 'autotelic' and is somehow a sign, as Berger (1972) affirms, of transcendence.

\section{The homo religious humanity model}

First of all, this humanity model is understood by the experience of the sacred, where humans gradually become aware of the sacred principle called the numinous which has four dimensions: the feeling of being a creature, the mysterium tremendum -the feelings of fearful experiences- , the fascinosum -the feelings of extraordinary and marvellous experiences - and mysterium -the feelings of the unkown and mystery experiences- (Otto, 1923). For Durkheim (1915), the sacred has social origin. It is the society which gives the foundation for transcendence. In other words, it is the society which creates and celebrates its gods. The sacred is consequently viewed as the perfect form of society. The homo religious is defined by a deep sense of the sacred that leads to the consciousness of God (Ries, 1984), where the building of 'religion' and 'spirituality' take form. For Dufour (1980), most people are desecrated and secularized. Beneath their appearance, they are more religious than ever. They have found their deep and profound religious selves. They have also moved away from institutional religion and have created a multitude of new ways of living. According to Eliade (1959), the homo religious believes that the cosmos 'talks' and 'lives' as a supernatural phenomenon. The cosmos is proof of its holiness since it was stimulated by the gods, and the gods manifest themselves to people through cosmic events as a higher power in particular forms of hierophanies. These sacred realities unfold through natural forces such as a stone, a tree, an animal, a storm or a person. Thus the people may be projected without warning into some kind of cosmology. This aspect of life refers to a vision of the world as 'analagon', which is a material form to target a sense of meaning (Wunenberger, 1977).

Also for Visker (1994/2004), any sphere of life and not only the church or religion, but also business, politics, education, sports, and so forth are considerated sacred. Television transmits a powerfully charged imagination, where the images cascade away in front of the viewer's eyes who witness political, military, sports and socio-cultural events. As Wunenberger (2006) writes, the television image causes, at this point, a kind of fascination for the viewer. The sacred images then become an instrument of fantasy liberating us from the prison of our body and throwing us into a sphere of representation in which we access a panvision that is to say the visualization of the whole social world and the communities. These images can be found through technicological developments such as Internet and cellular phones which create a virtual cyberspace where each human becomes the central actor/actress of his/her own life (cf. Levy, 1998). From this perspective, people have several values that need 
clarification from time to time (Laprée, 2000). Religious people have transcendant experiences, which allow for hopefulness, joyfulness and peacefulness.

\section{The homo faber-religious-ludens spiritual model of leisure: defining our vision by the interplay of three humanity model}

The conceptual definitions of these three humanity models -homo faber, homo ludens and homo religious - cannot be isolated, analysed and justified separately because they form inevitably a continuum on which people are situated. Thus they are permanentely in relationships with each other, and give a sense of meaning to a better leisure spiritual lifestyle. The interplay between these three humanity models provides an anthropological transformation perspective to the social world and the communities of todays's post secular era. This matter means that people change radically their state-of-being in life. In general, the people tend to follow the humanity model of homo faber, as the techno-scientific world continues to pursue the satisfaction of the basic needs of life. If homo faber priotirizes 'doing', people will be driven to work more than necessary with limited inner ressources. However, this is not the only humanity model, which creates a person's identity in everyday life. The homo ludens humanity model is another alternative for building human identity with its emphasis on cultivating a playful self-care and creation of one's self. People might as well temporarily enjoy the unreality of play. Obviously, life is not only for playing, and people sometimes find in situations where they feel like strangers to themselves or alienated from each other. They certainly need to be revitalized by the homo religious humanity model which in the Christian worldview, is through Jesus Christ who is the Saviour of humanity. When homo faber and homo ludens are educated by the teachings of the Lord Jesus who is in Christianity is the incarnation of God and the ultimate revelation of homo religious, then work and play may occur together in Christ resulting in a radical leisure state-of-mind where the experience of spiritual well-being is possible. Thus the work of homo faber call for the necessary recovery time found in the intense play of homo ludens and is regulated by the profound guidance of homo religious. These relationships result in the renewed energy required to return to work with a leisure state-of-mind which is a gracious blessing of God. Thus the integration of the three humanity model of leisure is established and contitutes the homo faber-religious-ludens spiritual model of leisure.

Besides, Parker (1975, p. 100) asked these questions: 'what is the relationship between behaviour and attitudes in leisure and other spheres? To what extent can systems or action theory guide us in understanding leisure 
phenomena?' Parker's questions inspire a definition of the homo faberreligious-ludens spiritual model of leisure:

Persons are fully engaged in the existential pursuit defined by the homo faberreligious-ludens for their inner and vital renewal process through the spiritual quest for leisure in spite of the struggle for life. This situation is often characterized by persons working and playing with religious or spiritual attitudes. Therefore, persons may find their radical identity being at leisure in today's post-secular era.

(Deschênes, 2016, p. 51)

This definition emphasizes transcendence and an eternal vision which is more fully explored below. In order to illustrate the homo faber-religiousludens spiritual model of leisure, some basic principles of philosophical hermeneutics method used in this study, will be explained.

\section{Method: the hermeneutical approach}

Hermeneutics draws attention to the inter-subjectivity of people who seek to assume their own act of existing in the world by being personally receptive to the experience as it is (Rogers, 1967) engaged between the required resistance or passive non-resistance to events in everyday life (Spohn 2000/2010). Ricoeur (2003) affirms that from a culture of compassion, the sufferer is searching for meaning; this implies the question of 'why'. The connection between suffering and the why of suffering cannot be deconstructed. Likewise, we tell stories using various language forms such as symbols, myth, poetry and narrative (Ricoeur 1983/1984), which are determined as a collection of relationships (Lévy-Strauss, 1958). The substantial nature of work and play are considered metaphors and represent the emergence of language through personal religious/spiritual transformations.

Ricoeur's (1977/2003) hermeneutical definition of the metaphor is a strategy of discourse preserving and developing the heuristic creative power of language by fictions in which the rhetorical process unfolds and describes the social world and communities' realities. For Kelly (1987, p. 3), the metaphor is also defined as 'something like this', which means that if you understand something from one viewpoint, you might also understand it from another viewpoint. Then, metaphors open up the possibility of viewing this sense of meaning through a multiplicity of signs and images. Bachelard (1948/2011) argues that images are first of all psychic forces stronger than ideas and normal human experiences. They get released from the intimate self and distributed into ourselves to where the world of imagination is created with no internal contradictions (Bachelard 1940/1968). The value of an image is evaluated by the extent of its imaginary halo. Therefore, imagination is essentially open and evasive; it is contained in the person's psyche which is 
open to spiritual experience and novelty. Imagination is primarily a type of the most vivid spiritual mobility and fecundity (Bachelard, 1943).

Nevertheless, in the sixteenth century, St. Teresa of Jesus mentioned the important role of the imagination in the contemplative act of oration and writes that the lack of scientific knowledge about the imaginative dimension of faith is a source of suffering for religious people (St. Teresa de Jésus, 1949/ 1577). The world of imagination is part of human development that creates meaning in life through gospel stories. From there, the consideration of a symbolic world is valuable in Durand's imaginary theoretical framework (Durand, 1960/1992, 1964). The symbols fulfill the power of imagination and, at the same time, are a sign of recognition. For Durand, the symbol gives something about which to think and dream; it is only valid for itself and is the epiphany of a mystery which displays a langage for Christian believers. Durand (1960/1992) affirms that symbolic language takes shape through the anthropological journey, i.e., the constant exchange that exists as imaginary impulses between subjective and objective assimilation to, and intimations from, the cosmic and social world, in which is revealed the pervasiveness of the symbolic life for humans. Within Christiatnity, the submission of any personal imagination occurs only through the mysterious revelation of the Holy Spirit of God and certainly not from limited human strenght. Among the riskiness of the mutilated thought and events of barbarism that are now unfolding before us (Morin, 2005), we must learn to retrieve the good from all evil, to extract the flower from the mud of evil (Xiberras, 2002), so we can find hope and happiness.

\section{Scriptural reading of the homo faber-religious-Iudens: Jesus Visits Martha and Mary (St. Luke 10: 38-42)}

In order to illustrate the spiritual model of leisure known as homo faberreligious-ludens, we will now use hermeneutics to investigate a sequence of images found within the gospel story Jesus Visits Martha and Mary (St. Luke 10: 38-42) with the Lord Jesus as homo religious.

The ternary relationships between the homo faber, the homo ludens and the homo religious is progressively revealed in the gospel story Jesus Visits Martha and Mary (St. Luke 10: 38-42). Ricoeur (1985/2012) asserts that the struggle against forgetting implies a daily wisdom through the appearance of the immemorial: what is ageless always remains. Above all, this text is a proclamation of the good news using the characteristic language of St. Luke who shows the importance of listening primarily to, and remembering the words of Jesus (Brown, 1997). Fox (2009) emphasized that this canonical evangelist and physician is a real storyteller, who addressed and adapted his gospel to the multicultural forces of a non-Christian-Judaic audience in the ancient Mediterranean society (70s and 80s CE), and 
highlighted activities and settings that are associated with leisure: eating and sharing food, socializing, and travelling to natural settings. In other word, we should remember that people of the first century in Palestine enjoyed good meals and feasts because they provided the opportunity to be happy and forget the harsh reality of a difficult life, the demanding religious system, the Roman military occupation and the possibility to die young. It is important to keep this socio-cultural context in mind reading the following account of Jesus Visits Martha and Mary:

\footnotetext{
${ }^{38}$ Now as they went on their way, he entered a certain village, where a woman named Martha welcomed him into her home. ${ }^{39}$ She had a sister named Mary, who sat at the Lord's feet and listened to what he was saying. ${ }^{40}$ But Martha was distracted by her many tasks; so she came to him and asked, 'Lord, do you not care that my sister has left me to do all the work by myself? Tell her then to help me!' ${ }^{41}$ But the Lord answered her, 'Martha, Martha, you are worried and distracted by many things; ${ }^{42}$ there is need of only one thing. Mary has chosen the better part, which will not be taken away from her'. (Canadian Bible Society, 1991/2012, St. Luke 10: 38-42, NRSV)
}

An initial observation should be made here. This gospel story contributes an understanding of a sphere of reality initially characterized by the pragmatism of Jesus' genuine concern about everyday life experiences, and as such, it has in return a normative effect. At first glance, this gospel story seems banal and ordinary. However, it has unpredictable eschatological consequences, i.e., hosting an important guest in a family circle. Thus, the Lord Jesus reveals how to behave and react toward His human-divine supernatural person who is the role model in the kingdom of heaven. It is also a call to a life of service. Creating such a life allows for discovery and enables a Christian worldview that is in contrast to the overwhelming impact of mass media and technology including electronic devices. Jesus' vision brings changes despite resistance and rejection around him. As a sign of the kingdom of heaven, He uses images that make sense and create powerful connections to various meanings in listeners' lives (Ricoeur, 1998). Within the spoken tradition, Jesus provides rules of conduct and suggests a way of living and applying faith in the social world and the communities of today's post-secular era.

The gospel story Jesus Visits Martha and Mary is set in a small village called Bethany, located about three kilometres from Jerusalem. The name Martha comes from the Aramaic language meaning 'lady' or 'mistress' (Brownrigg, 1971, p. 279), whereas the name Mary comes from Hebrew and means 'obstinacy' (Brownrigg, p. 281). Jesus is familiar with Martha and Mary as well as their brother Lazarus. He encounters two particular lifestyles in the clear distinction between these two sisters' personal attitudes. St. Luke does not fail to describe their distinctive characters arising from their personality traits as reported by Zwilling (2008): Mary is silent, 
immobile and concentrated while Martha is too busy, uncertain, anxious and even distracted. Mary is the opposite of Martha. The difference between these two sisters is also marked in their relationships to Jesus: Martha's relationship to Him is based on the meeting of daily needs such as the need for food and shelter; Martha welcomes Him while Mary listens to Him; Martha receives Jesus, speaks to Him, but does not plainly listen. Mary does not receive Jesus, does not talk, but she is receptive to His words. Each sister then takes a specific position and attitude in relation to the Lord Jesus.

More specifically, Martha is conflicted by the two immediate demands: creating a meal for her guests, and paying attention to what Jesus is saying. In some ways, she apprehends the world whereby there shall be no meal service because Jesus claims all her attention at the present time. She is torn from all sides and inside. So many things about this meal preparation absorb, confuse and distract her. Her care for Jesus focuses on something else. She feels alone and looks to the future with anxiety by anticipating, accelerating or blocking the action (Bovon, 1988), and therefore, Jesus discovers unhappily that Martha is impatient. She does not take the precious time to live and to enjoy His holy presence. Then, Martha tries to control her difficult situation. She is not in a sabbatical state-of-mind, and does not live in the moment. Perhaps one of the reasons why she behaved the way she did was because she was intimitaded by the presence of the Lord Jesus who was God Himself. She really wanted to do well, but was overwhelmed by the time it took to receive a person of distinction. Accordingly, she reacted in a manner that she did not reflect her true human and feminine nature. Bovon (1988) confirms that Jesus does not want to punish Martha. The Lord detects a legitimate concern in Martha's attitudes, but she is really anxious. Martha's restlessness is caused by the pressure she puts onto herself. She really feels abandoned by her sister and misunderstood by Jesus. The Lord does not doubt for a moment her desire to serve and complete the housework, however, He offers her a hierarchy of values and actions. The top priority is to listen to God's Word, to stop and take the time to sit with Him. This means not wanting to get ahead of the Lord, but accepting to be served by Him before serving Him. This is the one and only thing required that meets the needs of each person. This is the better part that corresponds to the desire of all. Moreover, Martha has not fallen into the world of darkness; she just feels it is threatening, and her agitation causes her to retreat from the loving guidance of Jesus. He does not want to relieve her of meal service. He just wants to eliminate her fear of being alone at work and to remove the heavy burden and negative emotions off from her shoulders that make her falsely believe that God is inactive because first 'for You [God] made us for Yourself, and our heart is restless, until it repose in You' (St. Augustine of Hippo, 397-401, p. 1). 
From this viewpoint, time of rest is always an eternal experience given freely by the Heavenly Father in everyday life.

After His public teaching, Jesus is exhausted and needs to slowdown. $\mathrm{He}$ is seeking moments of serenity, refreshment and legitimate tranquility. Mary really cares with her whole person by staying silent to listen to the words of Jesus, who teaches the kingdom of heaven. She relies on Jesus' rest by listening to Him. She is easily satisfied with the human presence of Jesus. More profoundly, Mary accepts the world as it is by waiting for the kingdom of heaven. She just wants to let the events unfold by themselves. Thus Mary is not busy, but allows things to happen (Pieper, 1952) which are the relaxed, trusting and restful attitudes Jesus really wants.

This gospel story brings together the features of the homo faber and the homo ludens humanity models. To some extent, Martha as homo faber portrays the attitude of false greatness based on world conquest, whereas Mary as homo ludens depicts true greatness, which corresponds in this case to her playful and seeking lifestyle (Weil 1949/2002). The homo faber humanity model is a deadly trap, because men and women are not strictly created with the need to work. When they find themselves unemployed or incapable of working, they feel empty and even worthless compared to those who hold economic exploitation, overconsumption, high productivity and extreme perfectionism values. In contrast, the homo ludens humanity model is considered as the appreciation of playing, which procures the determination of being what humans are in their playful, creative and imaginative deep-down personal selves with a sense of commitment to each other.

Martha personifies the homo faber humanity model. She is preoccupied with serving a meal that she made relatively complicated because of her anxiety. By doing too much, she tries to please Jesus, and He notices her. However, she is trapped in the iron cage of homo faber (Weber, 1904-1905/ 2012). This metaphor refers to a high-production system that controls and organizes working conditions. The purpose of the iron cage is to optimize the production economy rather than search for consultation and authentic cooperation from a humanitarian perspective. Martha is desperately locked in the determinism of meal organization and home management by seeking performance at all costs. She is a prisoner in this overly excessive production rationality. To summarize the teachings of Meister Eckhart (1981, p.293), Jesus addresses this friendly warning to Martha so she may be pure and free of caring. She needs to practice the act of detachment: 'Now a heart that has pure detachment is free of all created things, and so it is wholly submitted to God, and so it achieves the highest uniformity with God, and is most susceptible to divine inflowing'. Jesus observes that the obligations of service management, determined only by the restrictive homo faber humanity model, is producing anxiety and confusion in Martha. Ostensibly, Jesus moves away from Martha's cares. 
Mary represents the homo ludens humanity model. She is receptive to the teachings of Jesus with her sensitive, responsive, peaceful, grateful and positive attitudes. Because of her human nature, in all probability she preserves a secret love for Him, or at least she hopes for a sincere friendship with the Lord Jesus (Guitton, 1956). She is also engaged playfully; standing quite consciously outside 'ordinary life' (Huizinga 1938/1955). At the same moment, Mary is intensely and utterly absorbed by the words of Jesus inside a free activity connected with no material interest and no profit to be gained by it. She is in a holy playful state-of-mind while leaving room for rest, relaxation, celebration and contemplation, mainly to meet the Lord Jesus, a heartfelt path to happiness. Mary, as homo ludens, openly displays a playful attitude that reflects a willingness to freely follow Jesus. Actually, this gospel story demonstrates the importance of listening to God's Word in relation to family relationship concerns (Zwilling, 2008); Mary is just as engaged as Martha, but with a different focus. For Jesus, hospitality implicates more than a sumptuous banquet; it includes friendly attention and is a situation for enjoyment and for play. It is not merely a duty (Johnston, 1983). In brief, Mary carries out the good will of Jesus. He says that she is the one who definitely obtains the best part, which shall never be removed from her because she is the 'one who sees the practicability of the impractical, the value of playing around' (Miller, 1970, p. 176). As a consequence, Jesus clarifies the nature of the relationships between these two sisters. As Merton (1954/1981) propound, Martha and Mary were not foes; they were above all sisters. If they think otherwise, it was because of Martha's limitations to understand Mary's needs and why she did not have a more active part in the housekeeping, on the whole, that they shared together. It is then necessary to judge not on appearance but from the religion of the heart (Renan 1965/1863). Thus Mary is not the scapegoat of Martha. Jesus wishes for real harmony between the two sisters because life is very short and there is no time for fighting.

For Origen (1962), more profoundly, Martha bodily experiences in her home and soul the revelation of the Logos characterized by anxious feelings, whereas Mary quietly listens to the Wisdom of God at the Lord's feet. Origen does not reject at all the action of Martha, but makes it compatible with the contemplative lifestyle. For Bovon (1988), Martha belongs with Christian beginners, while Mary personifies the advanced Christian. Moreover, Neville (2004, p. 22) claims subtly that '[i]f there are two kinds of life, the active and the contemplative, they can be seen either as part of one individual's experience or as characteristics of the whole church embodied in different members'. Similarly, as Hesse (1949/2002) explained, humans must not escape the vita activa to take refuge in the vita contemplativa, or vice versa, but rather alternately follow one type of life and the other, acknowledge each of them within us. They participate in 
the pursuit of resting in the kindness of God (Ryken, 1995). In other words, it is a mistake to dramatically oppose these two humanity models which is considered in a dialectical way of being and living; because there is in everyone the potential of the outer and the inner person (Meister Eckhart, 1981). Thus they are at the same time two important parts of each human personality.

Martha as homo faber is structured primarily in the 'schizomorph/ heroic' polarity (Durand 1960/1992, Durand, 1964), which is the diurnal regime of images determined by patterns of separation, distinction and upward-rising momentum. ${ }^{1}$ Her heroic disposition helps to fight the harshness of life. Therefore, the 'schizomorph/heroic' polarity is concerned with the struggle for life. In actuality, Martha began her work with dignity by organizing the meal for the guests around her. Martha is a proud worker caring for Jesus' welfare. She is not giving up easily in front of adversity. However, by not being attentive to the words of Jesus, she becomes unwillingly affected by the clashing image of the unwise lady at home (Durand 1960/1992). The teachings of Jesus shake her faith, and then involve a change in attitude so that she follows His divine will to give salvation insights which lead to a better quality of life.

Mary definitely has real religious predispositions. She is part of the structural 'intimacy/mystical' polarity within the nocturnal regime of images which is determined by the intention to confuse, to mellow and to reduce conflictual tensions (Durand 1960/1992, Durand, 1964). ${ }^{2}$ Through the homo ludens humanity model, Mary is also engaged in struggling for something (Huizinga 1938/1955) by earning her own inner dignity, freedom and peace. She is playfully connecting to Jesus' divine will by listening to God's Word. Mary, who is truly playing, combines a desire for union with a sensitivity to secret intimacy (Durand 1960/1992). She is fully and emotionally connected to Jesus' teachings. Because of this liberating attitude, she plays like a mystic and becomes oriented to a life of leisure (Leclercq, 1957). She is one who respects Jesus' will, which enables her to cultivate a lovely friendship with Him. Being willing to play with Jesus first, Mary unwittingly develops, as the time goes by, her religious/spiritual personal identity.

The Lord Jesus as homo religious was considered mainly as a prophete and many women interested by what he was teaching followed him in most sites of Palestine. As such, his relationships with women were unique since women at that time were not considered to have social status. In fact, they were observed, as children, inferior in nature to men within a patriarchal system. Through his praxis, the Lord Jesus as homo religious teaches us non-resistance to evil forces. At the same time, He exhorts humans to assume their inner responsibility in front of hypocritical and controversial issues caused by the sacerdotal and secular authorities 
notably on economic matters and social injustices. He is also beyond the dilemma of the conflicting priorities between the two sisters. He teaches the kingdom of heaven as a new way of being and living without denying human nature. This means there is a leisurely way to accomplish His will while preventing alienation by homo faber's many requirements. Incidentally, the next pericope in St. Luke's Gospel is Jesus' Teaching on Prayer (11: 1-4) to His disciples. The Lord's Prayer for the homo religious is a profound daily meditation and conversation through the act of dialogue. With the practice of the faithful and ongoing prayer support, it expresses recognition of God's Spirit testifying to Jesus' sonhood when 'we cry, $A b b a$, Father' (Rm 8: 15). It allows us to halt and hold back the conflicts caused by the struggle of gods because, as Fox affirms, (Fox, 1934/ 1989), the Lord's Prayer is one powerful shared denominator of all the Christian Churches. In real life, all Christian children are taught the Lord's Prayer and many Christians who pray at all say this meditation and conversation with God mostly on a daily basis.

\section{The Lord Jesus as homo faber-religious-ludens}

The Lord Jesus is probably more than the homo religious humanity model in the social world and the communities of todays's post secular era. Of course, $\mathrm{He}$ is still, to some extend, homo religious with all His sacred qualities, which are revealed in various signs and miracles through history. Nevertheless, there are other humanity models that He embodied in His divine and human identity. It is well known that the Lord Jesus was a carpenter. He was therefore fully aware of the various challenges of the homo faber. In fact, the work of the carpenter was a lot of perspiration from cutting trees down and manipulating them. Once cut, the trees needed to be modified, planed, sanded and nailed. Subsequently, they were used for purposes such as building homes or repairing wooden devices, or for other common tasks. It is also well known that the Lord Jesus enjoyed participating in meals and feasts. He even revealed His glory in the village of Cana when He changed the water into wine at a friend's wedding. For Renan (1965/1863), His teaching was performed through some kind of perpetual feast in Galilee. In this way, the Lord Jesus showed that He liked to play with the guests by drinking wine, laughing and very likely dancing or singing. He was even accused by His ennemies of being a glutton and a drunkard. He had the human spirit that demonstrated the criterion of the homo ludens (Deschênes, 2011a). In that sense, as we noticed in the meal with Martha and Mary, the Lord Jesus needed to relax and slow down in order to achieve the leisure state-of-mind. Apparently, He involved the active presence and support of people around Him. During His historical passage on earth, the Lord Jesus needed to create meanings and relationships with people that $\mathrm{He}$ met. He shared views reciprocally and mutually in His relationship with Martha and Mary, 
the two close sisters. As a matter of fact, He provides strong images which shed light on an eternal vision by His capacity through His teachings to go back and forth between these three humanity models. ${ }^{3}$ The Lord Jesus represents relatively in His profound human and divine nature the spiritual model of leisure entitled the homo faber-religious-ludens, which is illustrated mainly by the various and mysterious human and divine relationship with Martha as homo faber and also Mary as homo ludens. He succeeded in resolving the conflict between the two sisters by seeking to harmonize opposites (Durand 1960/1992) and by showing His human behaviours to each of them. The meaning of all people is such that its expression reflects this double and combined vocation: to center in blossoming (Mounier 1950/1952). Jesus greatly loved Martha and Mary for who they were. He had the kindness to meet and respect them also the way they were, and taught them to communicate correctly and nicely with Him as $\mathrm{He}$ would with them. He creates meaningful connections between Martha and Mary and restores mutual complicity, complementary and reciprocity. The homo faber-religious-ludens spiritual model of leisure is present when Jesus' prayers coupled with His sympathetic behaviour and optimistic attitude support the unity of opposite personalities and lifestyles. By using and sharing their creative potential, they can develop and explore the true roots of their Christian identity as it should be. Therefore, this innovative attitude calls for communal spiritual practices such as prayers, meditation, conversation, listening to contemporary songs and classical/sacred music as an antidote to the pagan world's mistaken hyperindividualism when confronting evil social forces. This does not mean that Jesus as the Son of Man rejects the work of the homo faber as such, rather, He seeks to bring this humanity model's extreme perversions to our attention. Jesus teaches us that anxiety is the unhealthy attitude which is demonstrated by the propensity to look for signs of the kingdom of heaven: He suffered and died for us, he is resurrected, and intercedes for us, and thus those who believe are reconciled and shall reign with Him (Moltmann 1964/1967). In other words, Jesus as homo religious manages to solve the potential tensions between the two sisters. His historic passage on earth demonstrates at the same time His hypostatic personality, i.e., His fully human nature and His fully divine filiation that structures our divine destiny. It is then possible to explore all forms of people' spiritual realities in regards to various faith commitments inside a profound relationship with God in our world (Taylor, 1991). Meanwhile, Cox (1990, 2009) corroborates the resurgence of faith while clerical dogma seems to be dying unnecessarily. Cox (2009) writes that the spiritual, communal and justice-seeking dimensions of Christianity are now a leading edge in the 21 st century. This transformation is also happening in analogous reformations within other religions. The new Christian mysticism is turned toward 
the future where the kingdom of heaven is waiting for the conversion of humanity. Moltmann (2012) explains that this cosmic peace event happens the inner life of men and women in the post-secular era:

Just as the peace of God already dwells in the midst of the world, it is already present in the depths of human existence as well. 'Contemplation in a world of action' is the way Thomas Merton described the spirituality in which we find this peace in the resting point of one's own soul. On the one hand this peace of God is 'above' all understanding, and yet on the other hand it 'keeps our hearts and minds' and senses within us. Why? The reason Paul gives in Philippians 4.5 is that 'the Lord is near'. How near? As near as Christ is in us. According to Augustine, God is closer to us than we can be to ourselves. According to the Qur'an, God is closer to us than our jugular vein. (p. 239)

Therefore, management, leadership and spiritual guidance are needed with the practice of the faithful and ongoing prayer support which establishes a reconfiguration of religion. In the social world and the communities of today's post-secular era. This spiritual model of leisure entitled the homo faber-religious-ludens should also promote inspiration for other models of leisure such as Kelly's sociological model (1987), Csikzentmihalyi's sociopsychological model (1990) and finally Karlis, Grafanaki and Abbas's spiritual model (2002).

\section{Conclusion}

In this article, the homo faber-religious-ludens spiritual model of leisure is explored using the hermeneutics method. By being personally receptive to the experience as it is and engaged with the required resistance or passive non-resistance to events in everyday life, a new personal identity is achieved by the discovery of the dynamic dimension of this spiritual model of leisure. With the practice of the faithful and ongoing prayer support, it is then possible to change our way of thinking and to improve tolerance through God's revelation which create a renewed inner quest. In other words, consultation and authentic cooperation is demonstrated by the empowerment of education and anthropological transformation around us, which allow, by the grace of the Lord Jesus, a radical state-ofmind. This highlights, from time to time, the importance of people's need to recover and rest in Christ from the perversity of work - homo faber and the falsification of play - homo ludens -.

It must be underlined that the biblical account of Martha and Mary illustrated the relationship between the dimensions of productivity - homo faber - and playfulness - homo ludens - mediated by the praxis of the Lord Jesus' eschatological vision - homo religious -. Meaningful words of wisdom that we find in the Christian scripture are pronounced by Jesus in His sympathetic and optimistic way to prevent tensions between the faber and 
the ludens. His religious/spiritual teachings give hope, blessings, wisdom, peace of mind, and hapiness to all people that follow Him, leading to good will and mutual understanding.

Finally, this spiritual model of leisure develops a symbolic explanation and a substantial understanding of the meaning of life by the display of a langage for those who believe in the Christian faith. This model provides strong images which shed light on the eternal vision about the coming of the kingdom of heaven where people of faith shall be together for eternity. As each person is unique and sacred, this spiritual model of leisure shows the new Christian mysticism turned toward the future where the kingdom of heaven is waiting for the conversion of humanity in spite of the present religious crisis. Thus the homo faber-religious-ludens spiritual model of leisure emphasizes transcendance experiences that are signs of God.

\section{Notes}

1. The act of rising or standing is a dominant reflex. For example, when the persons are standing in front of a sunset, they feel the dichotomy between high and low, heaven and earth. The principle of exclusion, conflict and identity are predominant, while the verbal pattern is assigned to the order of 'distinguished'. It takes actions to rise, lighten, fight, conquer, purify, and illuminate whereas moods are expressed by words such as 'sky', 'sun', 'light', 'large', 'immense', 'divine', 'hard', 'gold', 'toughness', and so forth.

2. Digestive or swallowing gestures represent the dominant reflex. Principles of analogy and similarity characterize this polarity, while the verbal pattern is the predominant order of 'confused', where words like 'love', 'secret', 'dream', 'deep', 'mysterious', 'sad', 'pale', 'heavy', 'slow' and 'tenderness' reveal this structural polarity.

3. These strong images are developed through everyday life and belong intimately to each person on earth. They are definitively mysterious and come firstly from the Christian scripture. These images include, for example, when the Lord Jesus was having leisure experiences such as participating in meals or walking with His apostles in the countryside of Palestine, or laughing and making irony on many occasions, or playing with children. They occur also from time to time in our post-secular environment and are profoundly revitalized by prayers or any leisure experiences which bring meaning to life.

\section{Acknowledgments}

I would like to express my sincere gratitude to the reviewers and the associate editor who have contributed for the overall improvement of this article. My thankfulness is adressed in particular to the Editor-in-Chief, Dr Bryan Smale, for the management process of this writing project. My consideration goes also to Dre Heather Mair, Dr François Gravelle and Mrs. Monique Heintzman for the revision and editing task of that paper. I would like finally to say my recognition to the people who granted this financial support. 


\section{Disclosure statement}

No potential conflict of interest was reported by the author.

\section{Funding}

This work was supported by the Université du Québec à Chicoutimi [5000\$].

\section{References}

Bachelard, G. (1940/1968). The philosophy of no: A philosophy of new scientific mind. New York, NY: Orion Press.

Bachelard, G. (1943). L'Air et les Songes: Essai sur l'imagination du mouvement. Paris: José Corti.

Bachelard, G. (1948 /2011). Earth and reveries of repose: An essay of images of interiority. Dallas, TX: Dallas Institutes Publications.

Bellehumeur, C., Deschênes, G., \& Malette, J. (2012). L'imaginaire au cœur du développement psycho-spirituel des jeunes: Une réflexion interdisciplinaire sur la spiritualité de l'enfance et de la pré-adolescence. Studies in Religion/Sciences Religieuses, 41(1), 68-92.

Berger, P. L. (1972). La rumeur de Dieu, signe actuel du surnaturel. Paris: Centurion.

Bickley, P. (2014). The state of play. Swindon, UK: Bible Society.

Boeve, L. (2012). Religious education in a post-secular and post-Christian context. Journal of Beliefs and Values: Studies in Religion and Education, 33(2), 143-156.

Bovon, F. (1988). Luc le théologien: Vingt-cinq ans de recherches (1950-1975). Genève, CH: Labor \& Fides.

Braeckman, A. (2010). La religion dans l'espace public post-séculier, une confrontation critique des pespectives de Habermas et de Gauchet. Dialogue, 49(1), 53-72.

Brown, R. E. (1997). An introduction to the New Testament. New York, NY: Doubleday.

Brownrigg, R. (1971). Who's who in the new testament. New York, NY: Holt, Rinehart \& Winston.

Caillois, R. (1958 /1967). Les jeux et les hommes. Paris: Gallimard.

Canadian Bible Society. (1991/2012). Holy bible: New revised standard version. Toronto, ON: Bible Society Resources Ltd.

Cox, H. (2009). The future of faith. New York, NY: HarperCollins Publishers.

Cox, H. G. (1990). The secular city 25 years later. In The Christian century. 1025-1029. Chicago, IL: The Christian Century Foundation, 1025-1029. Retrieved from http:// www.religion-online.org/showarticle.asp?title $=206$

Csikzentmihalyi, M. (1990). Flow: The psychology of optimal experience. New York, NY: Harper and Row.

Deschênes, G. (2011a). Éléments de compréhension sur la praxis ludique de Jésus le Christ. Studies in Religion/Sciences Religieuses, 40(2), 177-198.

Deschênes, G. (2011b). L'anthropologie spirituelle du loisir: L'homo faber-religiosusludens. Counseling \& Spiritualité/Counselling \& Spirituality, 30(2), 57-85.

Deschênes, G. (2015). Allégories appliquées à l'humain producteur-religieux-joueur - Le loisir comme outils thérapeutique. Counseling \& Spiritualité/Counselling \& Spirituality, 34(1), 59-89. 
Deschênes, G. (2016). The homo faber-religiosus-ludens as a spiritual model of leisure through the aging process - A post-secular illustration of three beatles songs. Counselling and Spirituality/Counseling Et Spiritualité, 35(1), 47-66.

Dufour, R. (1980). Mythologie du week-end. Paris: Cerf.

Dumont, F. (1981). Une révolution culturelle ? In F. Dumont, J. Hamelin, \& E. J.-P. Montminy (Eds.), Ideologies du Canada-Français, 1940-1976, tome 1 (pp. 5-31). Québec: Presses de l'Université Laval.

Durand, G. (1960 /1992). Les structures anthropologiques de l'imaginaire: Introduction à l'archétypologie générale. Paris: Dunod.

Durand, G. (1964). L'imagination symbolique. Paris: Presses Universitaires de France.

Durkheim, E. (1915). The elementary forms of the religious life. London: George Allen \& Unwin Ltd.

Eckhart, M. (1981). The essential sermons, commentaries, traities and defense. New York, NY: Paulist Press.

Eliade, M. (1959). The sacred and the profane: The nature of religion. New York, NY: Harcourt Brace.

Fink, E. (1955 /2012). Oasis of happiness: Thoughts toward an ontology of play. Purlieu: A Philosophical Journal, 1(4), 1-27.

Fink, E. (1966). Le jeu comme symbole du monde. Paris: Minuit.

Fox, E. (1934 /1989). The sermon on the mount: The key to success in life. San Francisco, CA: Harper Collins Publishers.

Fox, K. (2009). Does the gospel of luke suggest a Christian-judaic of leisure in the graeco-Roman world. Leisure/Loisir, 33(1), 11-30.

Gallant, K., Arai, S., \& Smale, B. (2013). Celebrating, challenging and re-envisionning serious leisure. Leisure/Loisir, 37(2), 91-109.

Guitton, J. (1956). Jésus. Paris: Bernard Grasset.

Habermas, J. (2008). Qu'est-ce qu'une société 'post-séculière'? Le Débat, 5(152), 4-15.

Haworth, J., \& Lewis, S. (2005). Work, leisure and well-being. British Journal of Guidance \& Counselling, 33(1), 37-41.

Hesse, H. (1949 /2002). The glass bead game. New-York, NY: Macmillan.

Huizinga, J. (1938 /1955). Homo ludens: A study of the play element in culture. Boston, MA: Beacon Press.

Johnston, R. K. (1983). The Christian at play. Grand Rapids, MI: Eerdmans.

Karlis, G., Grafanaki, S., \& Abbas, J. (2002). Leisure and spirituality: A theoretical model. Society and Leisure, 25(1), 205-214.

Kelly, J. R. (1987). Freedom to be: A new sociology of leisure. New York, NY: Macmillan Publishing Company.

Kelly, J. R., \& Freysinger, V. J. (1999). 21st Century leisure: Current issues. Needham Heights: Allyn \& Bacon.

Lafargue, P. (1883/2012). The right to be lazy. Sainte-Pélagie Prison: The Anarchist Library. Retrieved from http://theanarchistlibrary.org/library/paul-lafargue-the-right-to-be-lazy. pdf.

Laprée, R. (2000). La psychagogie des valeurs. Montréal: Bellarmin.

Leclercq, J. (1957). L'amour des lettres et le désir de Dieu. Paris: Cerf.

Levy, P. (1998). Qu'est-ce que le virtuel ? Paris: La Découverte.

Lévy-Strauss, C. (1958). Anthropologie structurale. Paris: Plon.

Merton, T. (1954 /1981). Preface to the french edition of Martha, Mary et Lazarus. In R. E. Dassy \& T. Merton (Eds.), Introductions east and west the foreign prefaces of Thomas Merton (pp. 13-22). Greensboro, NC: Unicorn Press. 
Miller, D. L. (1970). Gods and games: Toward a theology of play. New York, NY: The World Publishing Company.

Moltmann, J. (1964 /1967). The theology of hope: On the ground and the implications of Christian eschatology. New York and Evanston, NY: Harper and Row Publishers.

Moltmann, J. (2012). Ethics of hope. Paris: Cerf.

Morin, E. (2005). Introduction à la pensée complexe. Paris: Seuil.

Mounier, E. (1950 /1952). Personalism. London: Routledge and Kegan Paul LTD.

Neville, G. (2004). Free time: Towards a theology of leisure. Birmingham, UK: University of Birmingham Press.

Origène. (1962). Homélies sur S. Luc. Paris: Cerf.

Otto, R. (1923). The idea of the holy (2nd ed.). New York, NY: OUP.

Parker, S. (1975). The sociology of leisure: Progress and problems. The British Journal of Sociology, 26(1), 99-101.

Parker, S., Ventris, N., Haworth, J., \& Smith, M. (1978). Society and leisure in contemporary society. Leisure Studies Association Conference Papers No. 1.

Pieper, J. (1952). Leisure: The basis of culture. New York, NY: Pantheon Books.

Renan, E. (1965 /1863). Vie de Jésus. Paris: Calmann-Lévy.

Ricoeur, P. (1977 /2003). The rule of metaphor: The creation of meaning in langage. London \& New York, NY: Routledge \& Kegan.

Ricoeur, P. (1983 /1984). Time and narrative-tome 1. Chicago: University of Chicago Press.

Ricoeur, P. (1985 /2012). Les temps du Dieu biblique. Esprit, 391, 110-125.

Ricoeur, P. (1998). Thinking biblically (with André LaCocque). Chicago, IL: University of Chicago Press.

Ricoeur, P. (2003). Psychanalyse et interprétation, un retour critique: Entretien avec Paul Ricoeur. Esprit, 420, 92-111.

Ries, J. (1984). Homo religiosus. In Paul Poupard (Eds.), Dictionnaires des religions (pp. 722-727). Paris: Seuil.

Rogers, C. R. (1967). Le développement de la personne. Paris: Dunod.

Ryken, L. (1995). Redeeming the time: A Christian approach to work and leisure. Grand Rapids, MI: Baker Books.

Schor, J. B. (1992). The overworked American: The unexpected decline of leisure. New York, NY: Basic Books.

Spohn, W. C. (2000 /2010). Jésus et l'éthique: 'Va et fais de même!'. London/Bruxelles: The Continuum International Publishing Group/Lessius.

St. Augustine of Hippo (397-401). Confessions of St. Augustine (Pusey's Translation of 1838; in a 'you' version). Retrieved from http://www.cormacburke.or.ke/node/1421.

Ste Thérèse de Jésus. (1949 /1577). Le château de l'âme ou le livre des demeures. Oeuvres complètes. Paris: Seuil. Trad. RP Grégoire de saint Joseph Carme Déchaussé.

Taylor, C. (1991). The malaise of modernity. Part 3 and 4 ideas with Paul Kennedy. Listen to the radio program "Interviews with Charles Taylor with David Cayley". Montréal: Radio program of Canadian Broadcasting Corporation (CBC). Retrieved from http:// www.cbc.ca/ideas/episodes/2011/04/11/the-malaise-of-modernity-part-1-5/

Visker, T. (1994 /2004). Play, game, and sport in a reformed, biblical worldview. In P. Heintzman, G. E. Van Andel, \& T. L. Visker (Eds.), Christianity \& leisure: Issues in a pluralistic society (pp. 164-181). Sioux Center: Dorth College Press.

Weber, M. (1904-1905 /2012). The protestant ethic and the spirit of capitalism. Abington: Routledge.

Weil, S. (1949 /2002). The need for roots. London: Routledge.

Wunenberger, -J.-J. (1977). La fête, le jeu et le sacré. Paris: Universitaires.

Wunenberger, -J.-J. (2006). L'imaginaire. Paris: Presses de l’Université de France. 
Xiberras, M. (2002). Pratique de l'imaginaire. Sainte-Foy: Presses de l'Université Laval. Zwilling, A.-L. (2008). Deux soeurs et Jésus, quel enseignement? (Luc 10, 38-42). In Bible et Terre Sainte. Mélanges Marcel Beaudry/2007. 223-235. Retrieved from http://halshs. archives-ouvertes.fr/docs/00/28/83/32/PDF/deux_soeurs.pdf. 